Section Editor

John J. Millichap, MD

\title{
Teaching NeuroImages: \\ Vanishing white matter \\ ovarioleukodystrophy
}

Shibani S. Mukerji, MD, $\mathrm{PhD}$

Florian S. Eichler, MD

Correspondence to

Dr. Mukerji:

smukerji@partners.org

Download teaching slides: Neurology.org

\section{Figure Brain imaging findings}

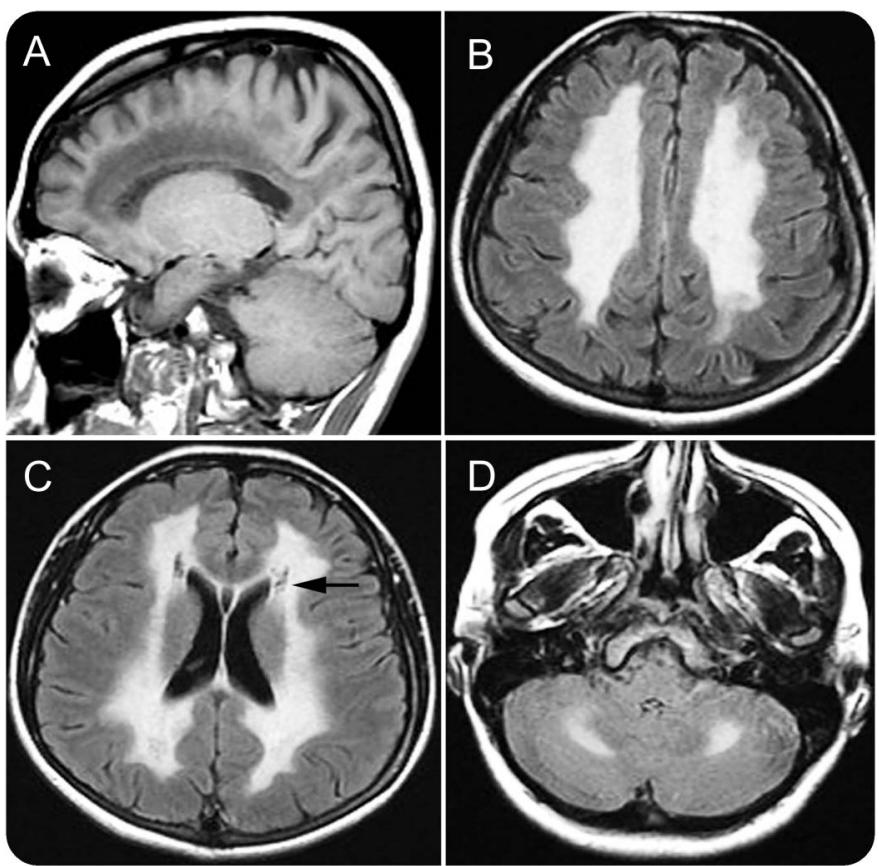

Hypointense signal is observed on sagittal T1-weighted MRI (A). Axial T2/fluid-attenuated inversion recovery sequences shows extensive, symmetric, confluent high signal intensity in the frontoparietal (B), periventricular (C), and cerebellar regions (D). Periventricular low signal intensity similar to CSF signal behavior is suggestive of cystic degeneration (arrow).

A 21-year-old Pakistani woman with a history of 2 seizures at 20 months of age and consanguineous parents was diagnosed with premature ovarian failure and hyperprolactinemia. Her neurologic examination was normal. Brain imaging showed confluent white matter T2/fluid-attenuated inversion recovery hyperintensities with periventricular cavitations (figure). Genetic testing showed homozygosity for a p.Lys273Arg missense mutation in the EIF2B2 gene (NM_014239.3: c. $818 \mathrm{~A}>\mathrm{G}$ ), which had previously been reported as disease-causing, ${ }^{1}$ and confirmed vanishing white matter (VWM) ovarioleukodystrophy. At 2-year follow-up, she remains neurologically asymptomatic with stable imaging. There is phenotypic variation in VWM disease and neurologic deterioration is associated with stressors (head trauma, fever). ${ }^{1,2}$

\section{AUTHOR CONTRIBUTIONS}

Dr. Mukerji conceptualized and designed the study, interpreted the data, and drafted the manuscript. Dr. Eichler interpreted the data and revised the manuscript for intellectual content.

\section{STUDY FUNDING}

Dr. Mukerji is supported by NIH T32 AG000222-23. Dr. Eichler is supported by NIH (NS072446, NS082331) and PI for phase II trial (FD00412703).

\section{DISCLOSURE}

The authors report no disclosures relevant to the manuscript. Go to Neurology.org for full disclosures.

\section{REFERENCES}

1. Leegwater PA, Vermeulen G, Konst AA, et al. Subunits of the translation initiation factor eIF2B are mutant in leukoencephalopathy with vanishing white matter. Nat Genet 2001;29: 383-388.

2. Fogli A, Schiffmann R, Bertini E, et al. The effect of genotype on the natural history of eIF2B-related leukodystrophies. Neurology 2004;62:1509-1517.

From the Department of Neurology (S.S.M., F.S.E.), Massachusetts General Hospital and Harvard Medical School, Boston; Center for Rare Neurological Diseases (F.S.E.), Massachusetts General Hospital, Boston. 


\section{Neurology}

\section{Teaching NeuroImages: Vanishing white matter ovarioleukodystrophy \\ Shibani S. Mukerji and Florian S. Eichler \\ Neurology 2016;86; 248 \\ DOI 10.1212/WNL.0000000000002764}

\section{This information is current as of June 13, 2016}

\section{Updated Information \& Services}

Supplementary Material

\section{References}

Subspecialty Collections

\section{Permissions \& Licensing}

Reprints including high resolution figures, can be found at: http://n.neurology.org/content/86/24/e248.full

Supplementary material can be found at: http://n.neurology.org/content/suppl/2016/06/11/WNL.0000000000002 764.DC1

This article cites 2 articles, 1 of which you can access for free at: http://n.neurology.org/content/86/24/e248.full\#ref-list-1

This article, along with others on similar topics, appears in the following collection(s):

\section{All Clinical Neurology}

http://n.neurology.org/cgi/collection/all_clinical_neurology

All Genetics

http://n.neurology.org/cgi/collection/all_genetics

Leukodystrophies

http://n.neurology.org/cgi/collection/leukodystrophies

MRI

http://n.neurology.org/cgi/collection/mri

Information about reproducing this article in parts (figures,tables) or in its entirety can be found online at:

http://www.neurology.org/about/about_the_journal\#permissions

Information about ordering reprints can be found online:

http://n.neurology.org/subscribers/advertise

Neurology ${ }^{\circledR}$ is the official journal of the American Academy of Neurology. Published continuously since 1951 , it is now a weekly with 48 issues per year. Copyright @ 2016 American Academy of Neurology. All rights reserved. Print ISSN: 0028-3878. Online ISSN: 1526-632X.

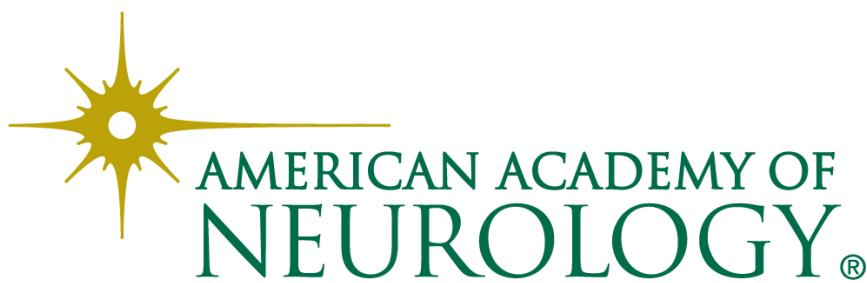

